\title{
A BRAZILIAN FAMILY WITH BROWN-VIALETTO- VAN LAERE SYNDROME WITH AUTOSOMAL RECESSIVE INHERITANCE
}

\author{
José Augusto Malheiros', Sarah Teixeira Camargos², \\ José Teotonio de Oliveira ${ }^{3}$, Francisco E.C. Cardoso ${ }^{4}$
}

\begin{abstract}
We report the first Brazilian family with Brown-Vialetto-van Laere syndrome. The presence of consanguineous marriages and illness affecting three sisters and one niece support an autosomal recessive transmission. The age at onset of the illness ranged from 12 to 20 years old. The time interval between hearing loss and involvement of other cranial nerves varied from 3 to 12 years. MRI demonstrated bulbar atrophy and also high intensity signal at T2 weighted and fluid attenuated inversion recovery (FLAIR) sequences.
\end{abstract}

KEY WORDS: Brown-Vialetto-van Laere syndrome, autosomal recessive inheritance, hearing impairment.

\begin{abstract}
Descrição de uma família brasileira com síndrome de Brown-Vialetto-van Laere com herança autossômica recessiva

RESUMO - Descrevemos a primeira família brasileira com síndrome de Brown-Vialetto-van Laere. Os pacientes são três irmãs e uma sobrinha provenientes de casamentos consangüíneos, o que fortalece a hipótese de transmissão autossômica recessiva. A idade de aparecimento dos sintomas variou entre 12 e 20 anos. A latência entre a perda auditiva e o envolvimento de outros nervos cranianos variou de 3 a 12 anos. 0 estudo de imagem por ressonância magnética demonstrou atrofia bulbar além de alteração de sinal nas seqüências ponderadas em T2 e FLAIR (fluid attenuated inversion recovery).
\end{abstract}

PALAVRAS-CHAVE: síndrome de Brown-Vialetto-van Laere, herança autossômica recessiva, surdez.

Brown-Vialleto-Van Laere Syndrome - BVVL- (MIM 211530), also called "Progressive Pontobulbar Palsy with Deafness" or "Bulbar Hereditary Neuropathy type I", is a rare entity with obscure etiologic aspects and several types of inheritance. Since its first description at 18941 there are about 43 cases reported in the medical literature ${ }^{2-8}$. The disease is characterized by neurosensorial deafness with a variable involvement of cranial nerves, usually motor components of seventh, ninth to twelfth nerves; besides an upper motor neuropathy. Disease progression varies since a very slow course with motor remitting and relapses until fatal death. Only sporadic cases have been described in Brazil ${ }^{9,10}$.

We report on a family with several cases of the disease in two generations of consanguineous marriages.

\section{CASES}

We examined four subjects of the second and third generation of the kindred (Fig 1).
Case 1 - At age 20, this 55 year female developed slowly progressive bilateral hearing loss and mild behavioral changes, followed years later by dysarthria, dysphagia, reduced visual acuity, muscle wasting and exercise induced shortness of breath. Cognition was normal. Examination demonstrated bilateral temporal optic paleness; best corrected visual acuity of 20/100, absent gag reflex, tongue fasciculation and proximal muscule weakness.

Tonal audiometry demonstrated neurosensory hearing loss with absence of responses on brainstem auditory evoked potential. Needle electromyography showed denervation especially in sterocleidomastoideus and trapezius. Spirometry and electrocardiography were normal. Magnetic resonance imaging of the brain demonstrated bulbar atrophy. Complete blood count and biochemistry tests were unremarkable.

Case 2 - At age 18, this 53 year old female developed bilateral hearing loss and dysarthria. Progressive muscle weakness developed nine years later. Examination demonstrated dysphonia, dysarthria, bilateral facial weakness, reduced gag reflex, tongue paresis and proximal muscle weakness more evident in the lower limbs. Deep tendon

Neurology Service, Department of Internal Medicine, Medical School, Federal University of Minas Gerais, Belo Horizonte MG, Brazil: ${ }^{1}$ Resident in Neurosurgery, ${ }^{2}$ Physician, ${ }^{3}$ Assistant Professor, ${ }^{4}$ Associate Professor. 


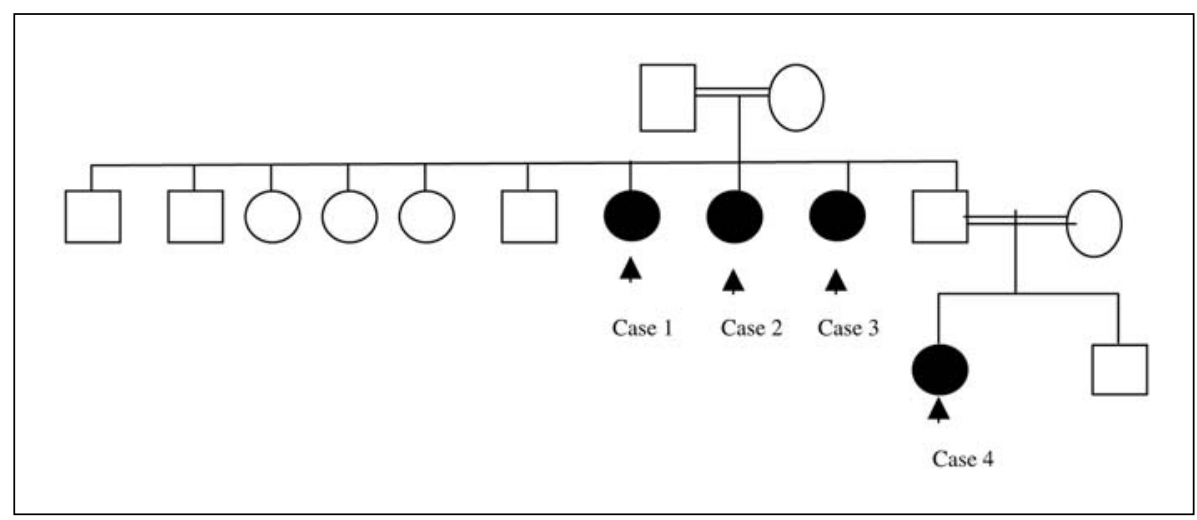

Fig 1. Family pedigree.

reflexes were normal. Audiometry demonstrated neurosensorial deafness.

Case 3 - At age 12, this 48 year old female developed hearing loss. At age 15, she presented with dysarthria, dysphagia, dysphonia and mild behavioral changes diagnosed as depression. At age 40 she also complained of exercise induced shortness of breath. Neurological examination she had tongue paralysis with widespread fasciculations, proximal muscle weakness more prominent in the lower limbs with normal deep tendon reflexes. There was no facial weakness. Audiometry demonstrated a severe neurosensorial hearing loss with no response on auditory evoked potential. Needle electromyography demonstrated denervation in the genioglossus muscle.

Blood chemistry, electrocardiogram, echocardiography, ergometric tests and spirometry were unremarkable. Cerebrospinal fluid cell count, protein, and glucose were normal. Hematoxylin-eosin stained muscle biopsy was normal. MRI T2-weighted and fluid attenuated inversion recovery (FLAIR) sequences demonstrated a bulbar high intensity signal (Fig 2).

Case 4 - At age 18, this 23-year-old daughter of the brother of three patients described above developed progressive isolated hearing loss. Neurological examination and audiometry demonstrated only bilateral neurosensorial hearing loss.

\section{DISCUSSION}

BVVL (Bulbar Hereditary Neuropathy type I) is a progressive pontobulbar palsy associated with a neurosensorial deafness. Oculomotor and trigeminal involvements are rare ${ }^{3,11}$. Sensorineural symptom in nearly all cases is the first symptom of the disease. There are only few cases reporting another symptoms preceding deafness. Sathasivam et al. described one patient which the onset of symptoms was slurring of speech and facial weakness ${ }^{12}$. Sumners at al. described a girl with limb weakness previous on neurosensorial deafness ${ }^{13}$. Hearing loss has been consis-

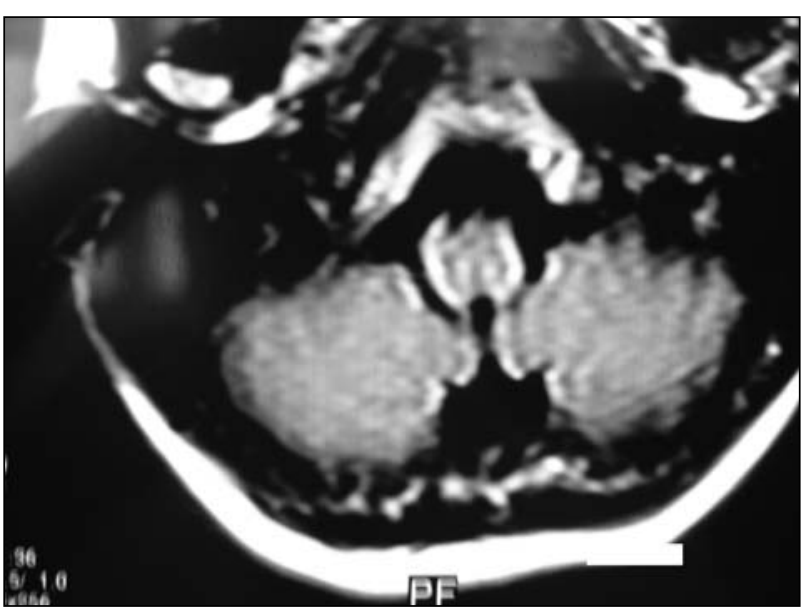

Fig 2. Brain MRI showing bulbar high signal intensity at FLAIR sequence.

tently described at the onset of the disease both in familiar and non- familiar cases.

The exception is Gallai's case ${ }^{14}$ with no evidence of hearing loss during the lifetime, although autopsy showed axonal loss on the $8^{\text {th }}$ nerve roots. Interval of time between hearing loss and the involvement of other cranial nerves has been variable from simultaneous involvement ( 5 cases) ${ }^{14-16}$ to a latency of 30 years ${ }^{17}$ as shown in Table. In our series, the time interval between hearing loss and involvement of other cranial nerves varied from 3 to 12 years. The disease progresses from a very slow course with motor remitting and relapses to death ${ }^{8}$. Fazio-Londe disease (Bulbar Hereditary Neuropathy type II) is the closest related syndrome but considered distinct from BVVL syndrome because of the absence of deafness ${ }^{18}$. Bolthauser et al. described a similar disease, but with different aspects from the BVVL: autosomal dominant inheritance and predominant presentation of vocal alteration with dysphonia and intermittent changes on voice pitch ${ }^{19}$. Madras variant of motor neuron dis- 
Table. Clinical summary of familiar reported cases of BVVL* (adapted from Mégarbané et al. ${ }^{15}$ ).

\begin{tabular}{|c|c|c|c|c|c|c|c|}
\hline Authors & Gender & $\begin{array}{l}\text { Age of } \\
\text { onset of } \\
\text { deafness } \\
\text { (years) }\end{array}$ & $\begin{array}{c}\text { Age of } \\
\text { onset of } \\
\text { cranial nerves } \\
\text { disability } \\
\text { (years) }\end{array}$ & $\begin{array}{l}\text { Time between } \\
\text { deafness and } \\
\text { cranial nerves } \\
\text { disability }\end{array}$ & $\begin{array}{l}\text { Age of } \\
\text { death } \\
\text { (years) }\end{array}$ & Consanguinity & Inheritance \\
\hline Present report & $3 \mathrm{~F}$ & $20,18,12$ & $20,27,15$ & $0,9,3$ & - & + & AR \\
\hline Ramarchandran et al., 2004 & $2 \mathrm{~F}$ & 7,8 & 10,11 & 3,3 & - & + & AR \\
\hline Megarbane et al., 2000 & $3 \mathrm{M}$ & $2.5,2.5,3.5$ & $2.5,2.5,3.5$ & $0,0,0$ & $-7,11$ & + & AR \\
\hline Davenport et al., 1994 & $1 \mathrm{~F}$ & Childhood & 18 & $?$ & - & - & $A D$ \\
\hline Hawkings et al., 1991 & $1 \mathrm{~F}$ & 12 & 13 & 1 & 17 & - & AR \\
\hline Gallai et al., 1981 & $1 \mathrm{M}, 1 \mathrm{~F}$ & $2,1.5$ & $14,1.5$ & 12,0 &,- 2 & - & AR \\
\hline Lombaert et al., 1976 & $1 \mathrm{M}, 1 \mathrm{~F}$ & $\begin{array}{c}\text { Childhood, } \\
17\end{array}$ & $? / 25$ & $? / 8$ & 19,25 & - & AR \\
\hline Boudin et al., 1971 & $2 \mathrm{~F}$ & 11,14 & $? / ?$ & $? / ?$ & $?$ & - & AR \\
\hline Van Laere, 1967 & $1 \mathrm{M}$ & 13 & 20 & 7 & $?$ & - & $A D ? X L$ \\
\hline Van Laere, 1966 & $1 \mathrm{~F}$ & 10 & 10 & 0 & $?$ & - & AR \\
\hline Vialetto, 1936 & $1 \mathrm{~F}$ & 0 & 30 & 30 & $?$ & - & AR \\
\hline Vialetto, 1936 & $1 \mathrm{~F}$ & 16 & 35 & 19 & $?$ & - & AR \\
\hline \multirow[t]{2}{*}{ Total } & $6 \mathrm{M}$ & Mean-10 & Mean-15 & Mean-6.2 & 6 & 3 & AR \\
\hline & $14 \mathrm{~F}$ & Median-10 & Median-14 & Median-3 & deaths & $\begin{array}{c}\text { consanguineous } \\
\text { families }\end{array}$ & $\begin{array}{c}\text { 10AR, } \\
2 A D, 1 X L\end{array}$ \\
\hline
\end{tabular}

F, female; $M$, male; $A R$, autosomal recessive; $A D$, autosomal dominant; $X L, X$-linked.

ease presents with an early onset of muscle and bulbar involvement, with deafness occurring in two thirds of the patients ${ }^{9,20}$. Some authors consider Madras variant as clinical spectrum of the same disease $^{13,20}$. Three cases of the present series have proximal muscle weakness, supporting this hypothesis. Madras variant, however, is sporadic condition with a benign clinical course.

Dyspnea has been reported in sporadic and familial cases of BVVL, especially in younger male patients ${ }^{18,21}$. This finding can be severe although there are reports of spontaneous improvement ${ }^{8}$. Cases 1 and 3 presented with dyspnea as a fluctuating symptom, although with mild functional impairment and normal pulmonary function tests.

Lombaert described in $1976^{22}$ severe neuronal changes in the brainstem reticular formation, but the reason for the fluctuating pattern is unknown. Several types of inheritance have been described in BVVL: autosomal dominant or an alternative $X$ linked $^{23,24}$ autosomal recessive ${ }^{15}$, besides sporadic cases and even from autoimmune origin ${ }^{25,26}$. The cases described in Brazil were all sporadic ${ }^{9,10}$, and the present series is the first with a clear autosomal recessive inheritance: the pedigree showing two generations of consanguineous marriages in witch all affected were females, strongly suggests this hypothesis. All cases described in the medical literature to date did not show any abnormality on imaging studies. We have found, however, a high intensity brainstem signal in the MRI (Case 3, Fig 2) suggestive of involvement of the pyramidal tract.

In conclusion, we have reported a family with consanguineous marriages where three brothers and one niece meet diagnostic criteria of BVVL. The inheritance of the illness is compatible with autosomal recessive transmission. One of our patients had hyperintensity of the brainstem in the topography of the pyramidal tract. This is the first described Brazilian familial case of BVVL.

\section{REFERENCES}

1. Brown $\mathrm{CH}$. Infantile amyotrofic lateral sclerosis of the family type. J Nerv Ment Dis 1894;21:707-716.

2. RamachandranNair R, Pameswaran M, Girija AS. Vialetto- Van Laere syndrome in two sisters born to consanguineous parents. Paediatr Neurol 2004;30:354-355.

3. Voudris KA, Skardoutsou A, Vagiakou EA. Infantile progressive bulbar palsy with deafness. Brain Dev 2002;24:732-735.

4. Introini S, Sasso GM, Moioli G, Morandini WL. Case report BrownVialetto-van Laere syndrome. Minerva Anestesiol 2003;69:75-79.

5. Aydin OF, Ozcelikel D, Senbil N, Gurer YK. Brown-Vialetto-van Laere syndrome: the first Turkish case. Acta Neurol Belg 2004;104:111-113.

6. Nemoto H, Konno S, Nomoto N Wakata N, Kiriraha T. A case of BrownVialetto-van Laere (BVVL) syndrome in Japan. Rinsho Shinkeigaku 2005;45:356-361. 
7. Prabhu HV, Brown MJ. Brown-Vialetto-van Laere syndrome: a rare syndrome in otology. J Laryngol Otol 2005;119: 470-2.

8. Grandis D, Passadore P, Chinaglia M, Brazzo F, Ravenni R, Cudia P. Clinical features and neurophysiological follow-up in case of BrownVialetto-van Laere syndrome. Neuromusc Disord 2005;15:565-568.

9. Oliveira JT, Moreira PR, Cardoso F, Perpetuo FO. Brown-Vialetto-van Laere syndrome: report of two cases. Arq Neuropsiquiatr 1995;53:789-791.

10. Rosemberg S, Lancelootti CLP, Arita F, Campos C. Progressive bulbar paralysis of childhood with deafness: case report with clinicopathologic correlation. Eur Neurol 1982;21:84-89.

11. Francis DA, Ponsford JR, Wiles CM, et al. Brown-Vialetto-van Laere syndrome. Neuropathol Appl Neurobiol 1993;19:91-94.

12. Sathasivam S, O`Sullivan S, Nicolson A, et al. Brown-Vialetto-van Laere syndrome: case report and literature review. Amyotroph Lateral Scler Other Motor Neuron Disord 2000;1:277-281

13. Summers BA, Swash M, Swartz MS, Ingram DA. Juvenile onset bulbospinal muscular atrophy with deafness: Vialetto-van Laere syndrome or Madras type motor neuron disease? J Neurol 1987;234:440-442.

14. Gallai V, Hockaday JM, Hughes JT, et al. Ponto-bulbar palsy with deafness (Brown-Vialetto-van Laere syndrome): a report of three cases. J Neurol Sci 1981;50;259-275.

15. Mégarbané AI, Desguerres I, Rizkallah E, et al. Brown-Vialetto-van Laere syndrome in a large inbred Lebanese family: confirmation of autosomal recessive inheritance? Am J Med Genet 2000;92:117-121.

16. Van Laere J. Paralysie bulbo pontine chronique progressive familiale avec surdité: un cas de syndrome de Klippel-Trenaunay dans la meme fratrie. Rev Neurol (Paris) 1966;115:289-295.
17. Vialetto E. Contributo alla forma ereditaria della pralisi bulbare progressive. Riv Sper Freniat 1936;40:1-24.

18. Voudris KA, Skardoutsou A, Vagiakou EA. Infantile progressive bulbar palsy with deafness. Brain Dev 2002;24:732-735.

19. Bolthauser E, Lang W, Spillmann T, Holf E. Hereditary muscular atrophy with vocal cord paralysis and sesorineural hearing loss: a dominant form of spinal muscular atrophy? J Med Genet 1989;26:105-108.

20. Gourie-Devi M, Suresh TG. Madras pattern of motor neuron disease in South India. J Neurol Neurosurg Psychiatry 1988;51:773-777.

21. Dipti S, Childs AM, Livingston JH, et al. Brown-Vialetto-Van Laere syndrome: variability in age at onset and disease progression highlighting the phenotypic overlap with Fazio-Londe disease. Brain Dev 2005; 27:443-446.

22. Lombaert A, Dom R, Carton H, Brucher JM. Progressive ponto-bulbar palsy with deafness; a clinicopathological study. Acta Neurol Belg 1976; 76:309-314.

23. Van Laere J. Over een newl geval van chosnische bulbopontiene paralysis met doofheid. Verh Vlaan Akad Geneesk Belg 1967;30:288-308.

24. Hawkins SA, Nevin NC, Harding AE. Pontobulbar palsy and neurosenssory deafness (Brown-Vialetto-van Laere syndrome) with possible autosomal dominant inheritance. J Med Gen 1990;27:176-179.

25. Sztajzel R, Kohler A, Reichart M, et al. Syndrome de Brown-Vialettovan Laere: un cas avec anticorps anti-ganglioside GM1 et revue de la littérature. Rev Neurol (Paris) 2002;154:51-54.

26. Davenport RJ, The Brown-Vialetto-van Laere syndrome: a case report and literature review. Eur J Neurol 1994;1:51-54. 